\title{
LTA4H Gene
}

National Cancer Institute

\section{Source}

National Cancer Institute. LTA4H Gene. NCI Thesaurus. Code C116949.

This gene plays a role in leukotriene metabolism. 